\title{
The Relationship Between Cognitive Styles and Play Behaviour of 5-6 Years Old Kindergarden Children
}

\author{
Neslihan Güney KARAMAN*
}

\begin{abstract}
The purpose of the research is to investigate the relationship between cognitive style and observed behaviour which according to cognitive and social play classification 5-6 years old children. The sample were 30 children who were 5-6 years of age, 19 girls, 11 boys. Pearson correlation's were (r) used to investigate the relationship between cognitive style of children and frequency of play; level of communication ability and leadership characters. In order to see the difference between field dependent / independent cognitive styles children in term of their frequencies of play; level of communication ability and leadership characters Mann Whitney U test has been used. Moreover, to see the difference between dependent / independent children in term of social play Kruskal Wallis H test has been used. No significant differences were found between field dependent/independent children in the measures of frequencies of play, level of communication ability and leadership characters, children in the study were 5-6 years old who mostly engage dramatic play due to their developmental characteristics.
\end{abstract}

Keyword: Kindergarden children, cognitive style, play

\footnotetext{
Assist.Prof. Baskent University, Faculty of Education, neslihanguney@yahoo.com
} 


\section{SUMMARY}

Purpose and Significance: The aim of the research is to investigate the relationship between cognitive style and observed cognitive and social behaviour of 5-6 years old children. Play is not only playful for children it is also one of the most important factors of emotional, social and cognitive development. Cognitive style of children provides insight about social relationships and their play behaviour which is very important part of their live as well. This research is a descriptive study on investigate the relationship between cognitive style and play behaviour of 5-6 years kindergarten children. The variables in the research are cognitive styles, play categories, and play behaviours in each play category and social play.

Methods: The sample was consisted of a total of 30 children (19 girls, 11 boys) within age range 5-6 years. The mean age of the group was 5 years 7 months.

In this research for cognitive style "Children's Embedded Figures Test" has been used. Children's Embedded Figures Test consisted of 25 items: an 11 item tent series in which a cut-out simple figure resembling a tent was embedded in a complex stimulus figure; and a 14 item house series in which a cut -out simple figure resembling a house had to be found in the complex stimulus figure. "Play Rating Scale" has been developed in order to be able to observe children's play behaviour. Play Rating Scale indicates children's play behaviours in the physical, block, manipulative and dramatic play areas which include four subscales. Each play category consists as: a) children's frequency of play, b) communication of ideas, c) levels of socialization, d) leadership proficiency.

Two observes provided r: 0.87 coherence between independent observes which an indicator of reliability is. Observation was made in three private kindergartens in Ankara. In a daily schedule, free play time in the workshop and late afternoon children were observed. Three kindergartens were similar to each other in respect to social and educational backgrounds. Pearson correlation's were (r) used to investigate the relationship between cognitive style of children and frequency of play; level of communication ability and leadership characters. Children were grouped on field dependent/ field independent based on each scores of and standard deviance values "Children's Embedded Figures Test". In order to see the difference between field dependent / field independent cognitive styles children in term of their frequencies of play; level of communication ability and leadership characteristics Mann Whitney U test has been used. Moreover, to see the difference between dependent / independent children in term of social play (ability of socialization) Kruskal Wallis $\mathrm{H}$ test has been used.

Results: No significant differences were found between fields dependent (FD)/ field independent (FI) children in the measures of frequencies of play, level of communication ability and leadership characters, children in the study were 5-6 years old who mostly engage dramatic play due to their developmental characteristic. But FI children tend to engaged more in dramatic play and cooperative play than did FD children, relatively. Because FI children rely on their own standards and values, solving difficult problems and having analytical skills.

Discussion and Conclusion: Results in general seem to yield no significant relationship between children's cognitive style and play frequency and play behaviour. Further research seems to be necessary to investigate possible relationships between cognitive development and play. 


\title{
Okulöncesi Eğitim Kurumuna Devam Eden 5-6 Yaş Grubu Çocukların Bilişsel Üslûpları ile Oyun Davranışları Arasındaki İlişkinin İncelenmesi
}

\author{
Neslihan Güney KARAMAN*
}

\begin{abstract}
ÖZ. Bu çalışmanın amacı, okulöncesi eğitim kurumuna devam eden 5 - 6 yaş çocuklarının bilişsel üslupları ile, bilişsel ve toplumsal oyun sınıflamasına göre, gözlemlenen oyunları arasındaki ilişkinin incelenmesidir.
\end{abstract}

\begin{abstract}
Araştırma, ilişkisel tarama modeli niteliğindedir. Araştırma için seçilen anaokullarından, 5-6 yaş gruplarından 19'u kı, 11'i erkek toplam 30 çocuk araştırmaya katılmıştır. Araştırmada çocukların bilişsel üsluplarını ölçmek için "Çocuklar için Gizlenmiş Şekiller Testi”, oyun davranışlarını gözlemlemek için, "Oyun Gözlem Formu"kullanılmıştır. Çocukların bilişsel üslup puanları ile oyun oynama sıklığı, iletişim becerisi düzeyi, liderlik özelliği arasındaki ilişkiyi incelemek amacıyla Pearson korelasyon katsayısı (r) kullanılmıştır. Alana bağımlı ve alandan bağımsız çocukların oyun oynama sıklıkları, iletişim becerileri ve liderlik özelliklerinin anlamlı farklılık gösterip gösteremediğini test etmek için Mann Whitney Utesti kullanılmıştır. Çocuklarca tercih edilen toplumsal oyun türüne göre bilişsel üslup puanlarının anlamlı farklılık gösterip göstermediği Kruskal Wallis H-testi kullanılarak analiz edilmiştir. Bu araştırmadan elde edilen bulgular, oyun seçiminde bilişsel üslubun belirleyici bir etkisi olmadığını göstermiştir. Ancak örneklemi oluşturan çocukların yaş düzeylerinin, oynadıkları oyun türünü etkilediği gözlenmiştir.
\end{abstract}

Anahtar kelimeler: Okul öncesi çocuk, bilişsel üslup, oyun

\footnotetext{
*Yard.Doç.Dr., Başkent Üniversitesi, Eğitim Fakültesi, neslihanguney@yahoo.com
} 


\section{GİRIŞ}

$\mathrm{Bu}$ araştırmanın konusu, 4-5 ve 6 yaşındaki çocukların bilişsel üslupları ile bilişsel ve toplumsal oyun sinıflamasına göre, gözlemlenen oyunları arasındaki ilişkinin incelenmesidir. Oyun, çocuk için sadece eğlenceli bir etkinlik değil, aynı zamanda onun duygusal, toplumsal ve bilişsel gelişimi için gerekli olan etmenlerden biri olarak görülmektedir (Rubin,1983). Çocuk oyun aracılığıyla pek çok davranışı ögrenir ve hem toplumsal hem bilişsel yönden gelişimi sağlanmış olur. Çocuğun oyun içindeki davranışı özgürdür. Çocuk oyun sayesinde, güvenli bir ortamda dilediği gibi davranarak, yaratıcılık, dil, toplumsal uyum gibi özelliklerini gösterme firsatı bulmaktadır ( Saracho,1996 ).

Çocuklar serbest oyun ortamında istedikleri oyunu seçerken, yaş ve bilişsel üslup bu seçimlerini belirleyen etmenlerin arasında yer almaktadır (Saracho,1995). Bilişsel üslubu bilmek, çocuğun davranışlarını anlayabilmek açısından gereklidir. Çocuğu iyi tanımak ve onun daha çok zaman geçirdiği oyunları belirlemek, çocuğun eğitimine de onun özelliklerini bilmek açısından yarar sağlayacaktır. Bu yolla eğitimcilerin, anababaların çocuğa yaklaşım tarzları, davranışları onu anlamaya yönelik olacaktır. Bilişsel üslubun bazı özellikleri oyun ile ilişkilendirilmiştir. Araştırmada bilişsel üslup, oyun ve yaş değişkenleri arasında bir inceleme yapılarak, bu çalışmanın, çocuğun bilişsel ve toplumsal gelişimi açısından eğitimine yol gösterici olması çalışmanın önemini oluşturmaktadır.

\section{Oyun}

Çocukluk, insan yaşamının en önemli sürecidir. Çocukların dış dünyaya ilişkin bilgileri oluşturması ve özümlemesi oyun aracılığıyla sağlanmaktadır. Çocuğun bu sayede bilişsel kapasitesi yapılanmakta, aynı zamanda çocuk topluma uyum sağlamaktadır. Piaget (1962) ve Vygotsky (1962)'ye göre oyun, çocukların bilişsel olarak büyümesi için temel kaynak olmaktadır. Vygotsky (1962)'ye göre oyun, çocuğun ileriki yaşlarında soyut düşünme yeteneğinin gelişmesinde, önemli bir role sahiptir (Akt. Saracho ve Spodek, 1998). Vygotsky (1967) çocukların dramatik oyun sırasında nesnelerle birtakım bilişsel dönüştürme yapmalarını, yaratıcılıklarının gelişmesi bakımından önemli bir adım olarak görmektedir. Çocuklar oyun sırasında yaratıcılıklarını ortaya koyarak, gerçek yaşamla ilgili hayali olaylar yaratmaktadırlar. Oyun aracılığıyla çocukların dil ve zihinsel becerilerinin gelişmesi sağlanmaktadır (Smalucha ve Smalucha, 1998). Özellikle oyunla ilgili olarak yapılan araştırmalara baktığımızda, oyunun ne olduğuna dair kesin bir tanımlamanın olmadığı sonucuna varılmıştır. Oyunun tanımlanmasıyla ilgili olarak, Piaget(1962) oyunu, kendiliğinden ortaya 
çıkan, zevk için yapılan, bir düzenleme içermeyen eğlenceli bir davranış olarak ele alarak, bilişsel gelişimin bir parçası olarak tanımlamaktadır. Vygotsky (1967) oyunun okul öncesi dönemde, gelişimin temel kaynağı ve soyut düşüncenin gelişiminde önemli olduğunu belirtmektedir. Ayrıca, oyunu bireyin çevre ile baş edebilmesi için kullandığı bir mekanizma olarak tanımlamaktadır.

Oyunun çocuğun yaşamına etkisinin farkına varılmasıyla, okulöncesi eğitim kurumlarında oyunun öneminin farkına varılması, oyun için ayrılan zamanın arttırılması yönünde çalışmaların olduğu görülmektedir.

Rubin, Fein ve Vanderberg (1983) oyunla ilgili araştırmaları inceleyerek, oyunun psikolojik özelliklerini aşağıdaki biçimde ifade etmektedirler:

Oyun; 1.İçsel olarak güdülenmiştir. 2. Amaçlardan çok araca önem veren bir süreçtir.

3. Keşfetme davranışından ayrılır. ("Bu nesne nedir?" yerine "Bu nesne ile ne yapabilirim?") 4.Gerçekdışı ve " - mış" gibi olması ile nitelenir.5.Dışarıdan uyarlanan kurallardan bağımsızdır. 6.Katılımcıların "aktif " olarak bu "işe" katılmasını gerektirir.

Piaget (1962) ' nin oyun sınıflaması: - Alıştırma Oyunu - Sembolik Oyun - Kurallı Oyun olmak üzere üç boyutta ele alınmıştır. Piaget çalışmalarında özellikle sembolik oyunun bilişsel gelişim için önemini vurgulamaktadır.

Smilansky (1968) oyun sınıflamasında, Piaget gibi, bilişsel gelişim evrelerini temel alarak, sembolik oyunun önemini belirtmiştir. Smilansky'nin oyun sinıflaması dört boyutludur. Bunlar: İşlevsel Oyun, inşa oyunu, dramatik oyun, kurallı oyun

Çocuğun toplumsallaşma süreci de oyunla başlar. Oyun ile birlikte çocuk kendisini arkadaş grubuna dâhil etme firsatı bulur. Oyunu daha da geliştirecebilecek beceriler kazanmaya başlar. Çocuk oyun ile birlikte yaratmaya başlamaktadır.

Parten oyunu çocuğun toplumsal katılımına bağlı olarak altı kategoride açıklamaktadır. Bu sınıflama şu şekildedir:

- Uğraşsız Davranış: Herhangi bir amacı olmadan boş dolaşma ya da sabit, anlamsız bir şekilde etrafını izlemek.

- İzleyici Davranış: Çocuk diğer çocukların etkinliklerini izler ama o etkinliklere katılmaz. 
- Tek Başına Oyun: Çocuk diğer çocuklara mesafeli bir şekilde, onların oyunlarına katılmadan, farklı materyallerle tek başına oynar.

- Paralel Oyun: Çocuk diğer çocuklarla arkadaşlık yapmadan; onlarla bir arada ya da onların oyuncaklarına benzer oyuncaklarla (Eckler ve Weninger, 1988) oynar, ancak diğer çocuklardan bağımsız olarak, tek başına oynadığı oyunlardır.

- Birlikte Oyun: Çocuk diğer çocuklarla birlikte oynar; ancak bir rol dağılımı ve örgütleme söz konusu değildir.

- İşbirlikçi Oyun: Çocukların oyunlarında, toplumsal bir etkinlik için ortak bir amaç vardır. Bu etkinlik ne olursa olsun, amaçları kesinlikle grupla birlikte hareket etmektir. İşbirlikçi oyun, örgütlenmiş bir grup içinde bir arada oynamaktır ( Akt. Rubin ve Coplan, 1998).

Her zaman oyunla ilgili olarak yapılan ilişkisel araştırmalarda, iki faktör arasında, oyunun problem çözme davranışına etkisi gibi, genel zekâ, bilişsel üslup gibi üçüncü bir faktör bu değişkenlere etki etmektedir (Akt. Smith ve Simon,1994). Bu konuda özellikle "bilişsel üslup" oyunu etkileyen önemli bir faktör olarak ele alınmaktadır (Saracho, 1995, 1996, 1999).

Piaget (2002) oyun ve bilişsel üslup arasındaki ilişkiye dikkati çekerek, bunu şu şekilde ifade etmektedir: "çocuklar, çevredeki bilgiyi elde etmede, bilişsel üsluplarına göre bir işlem gerçekleştirir".

\section{Bilişsel Üslup}

Bilişsel üslup, Witkin, Faterson, Goodenough ve Karp (1962) tarafindan, alg1, bellek, düşünme ve karar verme gibi bilişsel süreçlerde yararlanılan oldukça tutarlı bir yaklaşım biçimi olarak kabul edilmektedir. Witkin ve Goodenough (1981) bilişsel üslubu, sorunlara yaklaşım biçimi olarak tanımlamışlardır. Her bireyin soruna yaklaşım biçimi farklıdır. Bilişsel üslup, zihinsel yaşantılar ve bireysel algılama gibi farklı işlevlerde kendini göstermektedir (Saracho ve Spodek, 1998). Bilişsel üslup kavramı, farklı durumlardaki bireylerarası ilişkileri ve bilgiyi geliştirmeyi içermektedir (Saracho ve Spodek, 1998). Böylelikle, bilişsel üslup, alg1, bellek, düşünme, sorun çözme gibi tüm bilişsel süreçlerde etkili olmaktadır ( Kagan ve Messick,1976).

Bilişsel üsluplar, günlük yaşamda kazanılan basit alışkanlıklar ve öğrenme stratejilerinden önemli ayrılıklar göstermektedir. Çünkü bilişsel üsluplar yavaş yavaş ve deneyimlerle şekillenen birer kişilik özelliği olup, özel eğitim ya da öğrenme ve söndürme ilkelerinin uygulanmasıyla kolayca değiştirilemez ( Kagan ve Kogan, 1970; Kogan,1971). 
Bireyin davranış örüntüsü içinde yaygın bir alana ve çeşitli yönlere yansıdı ğ1 kabul edilen bilișsel üslup üzerine son 20-30 yıldır oldukça yoğun kuramsal ve görgül çalışmalar yapılmaktadır. Farklı kuramsal yaklaşımlar ve değişik teknikler kullanılarak yapılan araştırmalar sonucu, birbirinden farklı 15-20 kadar bilişsel üslup önerilmiştir (Kogan,1971). Ancak Kogan (1983) bu bilişsel üslupların sadece iki boyutu olduğunu ileri sürmektedir. Kogan gibi Witkin ve ark. (1962) da bilişsel üslubun iki boyutu olduğunu savunmaktadırlar. Günümüzde Witkin tarafindan öne sürülen, alana bağımlılık ve alandan bağımsızlık boyutları bir bilişsel üslup olarak ele alınmakta ve bunun kişilik, toplumsal değişkenler, algılama, bilişsel farklılıklar ve diğer psikolojik süreçlerle ilgili olduğu varsayılmaktadır (Witkin ve Goodenough,1981). Alana bağımlılık ve alandan bağımsızlık terimi ilk olarak algısal problemlerde, görsel ya da bedene bağlı olma eğiliminde bireysel farklılıkları anlatmak için kullanılmıştır. Bu konuda yapılan çalışmalar alana bağımlılık ile alandan bağımsızlık sürecinde çözümleme, yeniden yapılandırma (farklı şekilde örgütleyebilme) ve zihinsel etkinliklerin yer aldığını göstermektedir. Alana bağımlı ve alandan bağımsız bireyler alanla ilgili çalışmalarda farklıymış gibi görünseler de, gerçekte bireyin gelişimi her iki boyutu da kapsamaktadır. Bireylerden hiçbiri yalnızca tek bir boyut üzerinde yer alamamaktadır; bireyin bu boyutlarda yer alması bireysel özelliklere göre farklılık göstermektedir (Witkin ve Goodenough, 1981).Bireysel farklılık yaşa, cinsiyete, anababa tutumuna, eğitim düzeyine ve kültüre göre oluşmaktadır. Ancak bir bireyin bilişsel üslubunun başka bireyin bilişsel üslubundan farklı olması, bunlardan birinin daha iyi ya da kötü olduğu anlamına gelmemektedir (Dansky, 1980).

Alana bağımlılık ve alandan bağımsızlık boyutlarının bilişsel ve toplumsal alandaki etkinliklerinde, bireyin dış algı kaynaklarının daha az ya da daha çok etkisinde kalması eğilimi olarak tanımlanmaktadır. Alana bağımlılık ve alandan bağımsızlık boyutları arasındaki varolan temel farklılıklardan biri, "bilişsel yeniden yapılandırma" (cognitive restructuring) sürecinde, alandan bağımsız bireylerin, alana bağımlı bireylerden daha başarılı oldukları gözlenmesidir. Bilişsel yeniden yapılandırma, alandan bağımsız bireylerin, alanın karmaşık yapısını çözümleyecek öğelerini belirleme, belirli bir öğeyi karmaşık bir bütün içinden bulup çıkarabilme ve bunun sonucu olarak alanı görevin gerekleri uyarınca farklı örgütleyebilme olarak tanımlanmaktadır. Çünkü alana bağımlı bireyler kendi algılamalarından çok, alanın başat özelliklerinden daha fazla etkilenme eğilimindedirler. Alana bağımlı bireylerin, daha çok bilginin dış görünümüne önem verdikleri, bilişsel yeniden yapılandırma ölçütünde düzeylerinin düşük olduğu; alandan bağımsız bireylerin ise daha özenli işlev gördükleri, yeniden yapılandırma ölçütünde de yüksek düzeyde yer aldıkları ve kişilerarası ilişkilerinin düşük olduğu bulunmuştur (Witkin ve Goodenough, 1981). 
Toplumsallaşma, bireysellik ve bilişsel üslup değişkenleri arasında birbirini etkileyen ve birbirinden etkilenen bir etkileşim olduğu gözlenmektedir (Kogan ve Block, 1991). Her biri bir diğerini etkilemekte ve aynı zamanda ondan da etkilenmektedir. Alana bağımlı ve alandan bağımsız çocukları birbirlerinden ayıran, farklı toplumsal deneyimler ve farklı kişiliklere sahip olmalarıdır (Kogan ve Block,1991).

Toplumsallaşma açısından alana bağımlı ve alandan bağımsız bireyler arasındaki farklılık incelendiğinde, alana bağımlı bireylerin, alandan bağımsız bireylere göre, dış algı dayanaklarından ve diğer bireylerden gelen ipuçlarından daha fazla etkilendikleri ve bunun sonucu olarak da daha çok toplumsal olma eğiliminde oldukları ortaya çıkarılmıştır (Witkin ve Goodenough,1981). Kişilerarası ilişkiler ve karşılıklı olarak faydacı ilişkilerin alana bağımlı çocuklarda ve ergenlerde önemli olduğu, diğer taraftan alandan bağımsız çocuk ve ergenler arasında da, çok sıkı birbirine bağımlı olmayan ilişkilerin olduğu ve alana bağımlı çocuklardan farklı olarak bilişsel yetenekleri ve güdülenmelerinin gelişmiş olduğu savunulmaktadır (Kogan ve Block, 1991). Alana bağımlı çocukların arkadaş ilişkileri gelişmemiş, ayrışmamış kişilik özelliklerine dayanmaktadır ve arkadaş seçimleri gelişigüzel, rasgele olmaktadır. Alandan bağımsız çocukların toplumsal yeteneklerinin alana bağımlı çocuklara göre farklı olduğu açıklanmaktadır. Alandan bağımsız çocuklar duygular, gereksinimler ve başka kişilerin özelliklerini dikkate alma açısından kişilerarası ilişkilerle ilgilenirler; ancak bu çocukların özgürlükleri daha önemlidir. Bu çocuklar duygusal yönden sert olarak adlandırılmakta "uzak ve ayrı" olarak tanımlanmaktadırlar (Witkin ve ark., 1962).

Özetle, alana bağımlı ve alandan bağımsız bireyler, bilişsel, toplumsal ve duygusal yönlerden ele alındığında aralarında şöyle bir farklılık gözlenmektedir; alandan bağımsız bireyler, bilişsel davranışlarında, analitik; duygusal davranışlarında; kendi kendini kontrol eden ve kişilerarası davranışlarında, araç yönelimlidirler (instrumentally oriented). Kişiler arası ilişkilerinde, kişilerle birebir ilişkiye girmekten kaçınmaktadırlar. Öte yandan alana bağımlı bireyler, bilişsel davranışlarında kendiliğinden, kişiler arası davranışlarında gösterimcidirler (Gruenfeld, Linn, 1984).

\section{Oyun ve Bilişsel Üslup Arasındaki İlişki}

Bilişsel üslup gelişimsel bakış açısına göre değerlendirildiği zaman, genellikle yaşla birlikte alandan bağımsızlık yönünden bir artma olduğu ortaya çıkarılmıştır. Yapılan boylamsal araştırmalara göre, bireyin gelişimiyle birlikte oluşan değişikliklerde, ergenlik öncesi dönemden genç 
yetişkinlik dönemine kadar (Coates, 1972; Kogan, 1987), alana bağımlılıktan alandan bağımsızlığa doğru bir geçiş gözlenmektedir (Witkin, Dyk, Faterson, Goodenough, 1974; Witkin ve Goodenough,1981; Witkin, Goodeough ve Karp,1967; Witkin, Lewis, Hertzman, Machover, Meissner ve Wapner, 1972; Saracho, 1995).

Oyun çocuğun pek çok davranışı öğrenmesine olanak sağlayarak, gelişimine katkıda bulunmaktadır. Bu gelişiminin boyutlarından biri de çocuğun toplumsal gelişimidir. Mellon (1994) oyun çocukların kendi kendileriyle ve dış dünyayla etkileşimlerini sağlamaktadır. Çocuklar toplumun kurallarını paylaşmayı, işbirliğini, başkalarına yardımı ve problemlere farklı çözüm yolları getirebilme becerilerini bu sayede öğrenmektedirler (Saracho, 1987). Buna bağlı olarak, çocukların bilişsel üslupları (alana bağımlı / alandan bağımsız) ile toplumsallaşma düzeyleri oyun ortamında incelenmiştir. Coates ve ark. (1975) ve Steele (1981), okul öncesi dönemdeki alana bağımlı çocukların diğer gruba göre daha çok toplumsal oyun oynadıkları, oysa alandan bağımsız çocukların tek başına oyunlara katıldıkları ortaya çıkarılmıştır. Kogan ve Block (1991) ise alana bağımlı çocukların, alandan bağımsız çocuklara göre daha çok toplumsal davranış gösterdiklerini bulmuştur. Alandan bağımsız ve alana bağımlılık arasındaki bu farka göre, alana bağımlı- alandan bağımsız özelliklere sahip olan çocuklara bir kişilik testi uygulanmış ve bunun sonucu olarak, alana bağımlı çocukların alandan bağımsız çocuklara göre kişilerarası ilişkilerinin daha gelişmiş olduğu bulunmuştur (Kogan ve Block, 1991).

Coates, Lord ve Jocabivics (1975) tarafindan yapılan bir araştırmada ise alandan bağımsız çocukların toplumsal uyumları oyun ortamında incelenerek, aralarında bir ilişki olduğu ortaya çıkarılmıştır. Aynı araştırmacılar çocuklar arasındaki cinsiyet farklılığını incelemişler, kızlar ve erkekler arasında toplumsallaşma, uyum sağlama açısından kızlar lehine bir sonuç bulmuşlardır.

Saracho (1995, 1996 ve 1999) yaptığı çalışmalarda çocukların bilişsel üslupları ile oyunlarını yaş ve cinsiyete göre incelemiştir. Her iki alan arasında paralellik söz konusudur. Ona göre bilişsel üslup ve oyun kategorileri benzer özellikleri barındırmakta ve benzer toplumsal davranışları içermektedir. Bu da çocukların toplumsal yönden gelişimlerine katkıda bulunmaktadır.

Saracho’ya (1987) göre, çocukların bilişsel üslupları onların oyunlarına yön vermektedir. Başka bir deyişle çocuklar, oyunlarını bilişsel üsluplarına göre seçmektedirler. Steele (1981), Coates (1975) ve Saracho (1995, 1996 ve 1999) tarafından oyun ve bilişsel üslup arasındaki ilişki incelenmiştir. 
(Saracho; 1995, 1996, 1999), yaptığı bir dizi araştırmada çocukların bilişsel üsluplarıyla fiziksel, inşa, dramatik ve kurallı oyun kategorileri arasında yaşa ve cinsiyete bağlı olarak bir ilişki olduğunu savunmaktadır. Bu sonuçtan da anlaşılacağ1 gibi, belli bilişsel üsluba sahip çocuklar, tercih ettikleri oyunlarda yaşlarına ve cinsiyetlerine göre farklılık göstermektedir. Araştırmaların sonuçlarına göre, alandan bağımsız çocuklar daha çok toplumsal oyun oynarlarken, alana bağımlı çocuklar tek başına oynanan oyunları tercih etmektedirler.

Bilişsel üslup ve oyun arasındaki ilişkiyi inceleyen araştırmaların bulgularından hareketle, bilişsel üslubun, serbest oyun ortamında çocuğun farklı oyunları seçmesini etkilediğini göstermektedir. Bilişsel üslubun iki boyutu (alana bağımlılık/alandan bağımsızlık) da çocukların oyun ortamındaki toplumsal etkileşimlerinde önemlidir. Bunu destekleyen araştırmacılar da, çocuğun serbest oyun ortamındaki davranışlarını belirleyen temel etkenlerden biri olarak bilişsel üslubun bir boyutunu, alana bağımlılı̆̆ incelemişlerdir (Coates, 1975; Steele, 1981). Bilişsel üslubun her bir boyutu, çocuğun oyun ortamında, "nasıl" davrandığını açıklamaya yardımcı olmaktadır. Bilişsel üslubun iki özelliği burada dikkat çekicidir. İlki, bilişsel üslubun gelişimle birlikte değişebilmesi bir başka deyişle bir boyuttan diğerine doğru gelişimle birlikte geçebilmesi iken, diğeri cinsiyete göre farklılık gösterebilmesidir. Ancak burada toplumun beklentileri ve anababa tutumları ön plana çıkmaktadır.

Bütün bu etkenler göz önüne alındığı zaman, çocukların bilişsel üslupları ile oynadıkları oyunlar arasındaki ilişkinin yaşa göre belirlenmesi, çocukların bilişsel gelişimlerinin anlaşılması bakımından ipucu niteliğinde olmaktadir.

Özellikle çocukların bilişsel üsluplarının ilk yıllarda bilinmesi, öğretmenlerinin onları geliştirici yönde bir program hazırlamasında etkili olacaktır. Bu sayede öğretmen çocuğun bilişsel üslubunu ve oyun davranışlarını göz önüne alarak, çocuğun gereksinimlerini anlamayı öğrenebilecektir. Sonuçta çocukların gelişimlerinin daha nitelikli olması için eğitim programlarında bilişsel üslup ve oyun davranışlarının özellikleri yansitilmalidir.

\section{Araştırmanin amacl}

Araştırma 5-6 yaş anaokulu çocuklarının Smilansky'nin oyun sınıflandırması ile çocukların bilişsel üslupları arasındaki ilişki incelenmiştir. Araştırmada, okul öncesi dönem çocukların bilişsel üslupları ve seçtikleri oyun kategorileri arasındaki ilişki ve her bir oyun alanında değişimi incelenmektedir. 
Okulöncesi Ĕgitim Kurumuna Devam Eden 5-6 Yaş Grubu Çocukların... 173

\section{YÖNTEM}

\section{Araștırma Modeli}

$\mathrm{Bu}$ araștırma, okul öncesi eğitim kurumuna devam eden 5-6 yaş grubu çocukların bilişsel üslupları ve oyun davranışları arasındaki ilişkiyi incelemeye yönelik, betimsel bir araştırmadır. Araştırmada yer alan değişkenler; bilişsel üslup (alana bağımlı / alandan bağımsız), oyun kategorileri (fiziksel oyun, küp oyunu, manipülatif oyun ve dramatik oyun) ve çocukların her bir oyun kategorisinde gösterdikleri oyun davranışları (iletişim becerisi ve liderlik) ve toplumsal oyundur. Araştırmada bilişsel üslup ölçeği, Çocuklar için Gizlenmiş Şekiller Testi (Children Embeded Figures Test), puanları ile Oyun Gözlem Formuna göre belirlenen; oyun oynama düzeyleri, iletişim becerileri ve liderlik davranışları arasındaki ilişkinin irdelenmesinin yanı sıra, toplumsal oyun kategorileri ile sözü edilen değişkenler arasındaki ilişki de incelenmiştir. Bu anlamda araştırma, ilişkisel tarama modeli niteliğindedir.

\section{Araştırma Grubu}

$\mathrm{Bu}$ araştırmanın çalışma grubunu, Ankara 'da orta ve üst sosyo ekonomik düzeydeki üç ana okulundaki 5-6 yaş grubu çocuklar oluşturmuştur. Araştırma için seçilen anaokullarında, 5- 6 yaş gruplarından $18^{\prime}$ i kız, 12' si erkek toplam 30 çocuk, seçkisiz atama yolu ile belirlenmiştir. Seçilen gruplara önce çocukların bilişsel üsluplarını ölçmeye yönelik, Çocuklar için Gizlenmiş Şekiller Testi (Karp ve Konstand,1971) uygulanmış, oyun davranışlarını gözlemlemek amacıyla ise, Oyun Gözlem Formu (Saracho,1984) kullanılmıştır. Gözlemlerin yapılması ve ilgili testin uygulanması, Temmuz- Ağustos 2001 tarihleri arasında, anaokulların serbest oyun saatlerinde, yapılmıştır.

Çocukların sosyo-ekonomik düzeyleri, ailelerin aylık gelirleri ve eğitim durumları hakkında okullardan alınan bilgilere dayanarak belirlenmiştir.

\section{Verilerin Toplanması}

Araştırma sorularını yanıtlamak ve gereksinim duyulan verileri toplamak amacıyla, a) çocukların bilişsel üsluplarını ölçmek için "Çocuklar için Gizlenmiş Şekiller Testi” (Karp ve Konstand,1971), b) oyun davranışlarını gözlemlemek için de "Oyun Gözlem Formu" (Saracho, 1984) kullanılmıştır. 


\section{Verilerin Çözümlenmesi}

Okulöncesi eğitim kurumlarına giden 5-6 yaş grubu çocukların bilişsel üslupları ve oyunları arasındaki ilişkiyi incelemek amacıyla uygulanan "Çocuklar için Gizlenmiş Şekiller Testi" ve "Oyun Gözlem Formu" ndan elde edilen veriler, SPSS paket programı kullanılarak çözümlenmiş̧ir. Analizde kullanılan istatistiksel işlemler şu şekildedir:

1. Çocukların bilişsel üslup puanları ile oyun oynama sıklığı, iletişim becerisi düzeyi, liderlik özelliği arasındaki ilişkiyi incelemek amacıyla Pearson korelasyon katsayısı (r) kullanılmıştır. Elde edilen korelasyon katsayısı, istatistiksel anlamlılık ve ilişkinin yönü açısından yorumlanmıştır.

2. Bilişsel üslup ölçeği puanları ve puanların ortalama ve standart sapma değerleri temel alınarak çocuklar, alana bağımlı ve alandan bağımsız olarak iki kategoriye atanmıştır. Alana bağımlı ve alandan bağımsız çocukların oyun oynama sıklıkları, iletişim becerileri ve liderlik özelliklerinin anlamlı farklılık gösterip gösteremediğini test etmek için Mann Whitney U-testi kullanılmıştır.

3. Çocuklarca tercih edilen toplumsal oyun türüne göre bilişsel üslup puanlarının anlamlı farklılık gösterip göstermediği Kruskal Wallis H-testi kullanılarak analiz edilmiştir.

\section{BULGULAR VE YORUM}

$\mathrm{Bu}$ bölümde, ilk olarak çocukların bilişsel üslup ölçeği puanlarının dağılım özellikleri, ikinci olarak, çocukların bilişsel üslup puanları ile oyun oynama sıklıkları, liderlik özellikleri, iletişim becerisi arasındaki ilişki, alana bağımlı ve alandan bağımsız olarak ayrılan farklı bilişsel üsluba sahip çocukların oyun oynama sıklıklarına, iletişim becerisine ve toplumsal oyun sınıflamasına ilişkin değerlere yer verilmiştir.

Tablo 1. Bilişsel Üslup ve Oyun Oynama Sıklığı İle İlgili Puanların Dağılım Özellikleri

\begin{tabular}{lccccccc}
\hline \multirow{2}{*}{ Değişken } & $\mathrm{N}$ & $\overline{\mathrm{X}}$ & Ortanca & $\mathrm{S}$ & Çarpıklık & En Düşük Puan & En Yüksek puan \\
\hline Bilişsel üslup & 30 & 5,80 & 5,00 & 3,13 & 0,695 & 2,00 & 13,00 \\
Fiziksel Oyun & 30 & 3,90 & 2,00 & 4,59 & 2,15 & 1,00 & 20,00 \\
Küp Oyunu & 30 & 3,10 & 1,00 & 3,69 & 1,56 &, 00 & 13,00 \\
Manipülatif Oyun & 30 & 2,73 & 1,00 & 2,77 & 1,98 & 1,00 & 12,00 \\
Dramatik Oyun & 30 & 14,86 & 12,00 & 6,91 & 0,25 & 4,00 & 25,00 \\
\hline
\end{tabular}


Bilişsel üslup ölçeği puanlarının ortalaması 5,80, ortancası 5,00, standart sapması 3,13, en düşük değeri 2 ve en yüksek değeri 13' tür. Ortalama ve ortanca değerlerin birbirine yakın olması, puanların dağılımının normale yaklaşık olduğu şeklinde yorumlanabilir. Puanların dağılımına ait çarpıklık katsayısının da $(0,695) 1.00$ 'dan küçük olması, bunun bir diğer kanıtı olarak görülebilir.

Araştırmaya katılan çocukların, bilişsel üslup ölçeğinden aldıkları en yüksek puan 13 olurken, en düşük puan 2'dir. Bu sonuçlara göre, 5 ve 6 yaşlarındaki çocukların bilişsel üslup puanları alandan bağımsızlık yönünde bir değişim gösterme eğilimindedir. Çocukları, bilişsel üslup puanlarına göre alana bağımlı ve alandan bağımsız olmak üzere iki gruba ayırmak için ortalama ve standart sapma kullanılmıştır. Normal dağılım eğrisinde, ortalamanın bir standart sapma altında kalan çocuklar $(<\overline{\mathrm{X}}-0,5 \mathrm{~S})$, alana bağımlı olarak belirlenirken, ortalamanın bir standart sapma üzerinde kalan çocuklar $(>\overline{\mathrm{X}}+0,5 \mathrm{~S})$, alandan bağımsız olarak belirlenmiştir. Buna göre, bilişsel üslup ölçeği puanı 4 ve altında olanlar alana bağımlı ve 7 ve üstü puana sahip olanlar alandan bağımsız olan çocuklar olarak tanımlanmıştır. Öte yandan 5-6 puana sahip olan çocuklar ise, alana bağımlı / bağımsızlık açısından durumu net olmayan grup olarak saptanmış olup, bu grup karşılaştırmalarda analiz dışı tutulmuştur.

Deneklerin bilişsel oyun puanları ile oyun gözlem formu (OGF) aracılığıyla belirlenen oynama sıklıkları, iletişim becerileri ve liderlik özellikleri arasında anlamlı bir ilişkinin olup olmadığına ilişkin yapılan Pearson $r$ analizi sonuçları Tablo 2'de gösterilmektedir.

Tablo 2. Bilişsel Üslup Ölçeği Puanları İle Oyun Oynama Sıklığı, İletişim Becerisi ve Liderlik Özellikleri Arasındaki İkili Korelasyonlar ( $\mathrm{N}=30)$

\begin{tabular}{lll}
\hline Faktör & Pearson r & $\mathrm{P}$ \\
\hline Fiziksel oyun oynama sıklı̆̆ı & $-0,09$ &, 618 \\
Fiziksel oyunda iletişim becerisi & $-0,07$ &, 972 \\
Fiziksel oyunda liderlik özelliği & $-0,03$ &, 877 \\
Küp oyunu oynama sıklığı & $-0,03$ &, 859 \\
Küp oyununda iletişim becerisi & 0,04 &, 800 \\
Küp oyununda liderlik özelliği & $-0,09$ &, 607 \\
Manipülatif oyun oynama sıklığı & $-0,09$ &, 623 \\
Manipülatif oyunda iletişim becerisi & $0,39^{*}$ &, 033 \\
Manipülatif oyunda liderlik özelliği & $-0,11$ &, 554 \\
Dramatik oyun oynama sıklığ1 & 0,18 &, 319 \\
Dramatik oyunda iletişim becerisi & $0,38^{*}$ &, 036 \\
Dramatik oyunda liderlik özelliği & 0,23 &, 208 \\
\hline
\end{tabular}

$* \mathrm{p}<0,05$ 
Tablo 2'de görüldüğü gibi, bilişsel üslup puanları ile oyun oynama sıklığı, iletişim becerisi ve liderlik özelliği arasında anlamlı bir ilişkinin olup olmadığına ilişkin uygulanan pearson $r$ korelasyonel karşılaştırma sonucunda; manipülatif oyunda ortaya çıkan iletişim becerisi puanı, pearson $r$ değeri=0,39 $(\mathrm{p}<0,05)$ anlamlı iken, dramatik oyunda ortaya çıkan iletişim becerisi puanı da benzer biçimde, pearson $\mathrm{r}$ değeri $=0,38$ ile anlamlıdır $(\mathrm{p}<0,05)$. Ancak, analize dahil olan diğer değişkenler arasında istatiksel anlamda anlamlı bir ilişki bulunmamıştır. Dramatik oyuna ilişkin puanların ortalaması ve standart sapmasının ve pearson $r$ değerinin diğer gruplara göre farklı olması, hücreye düşen çocuk sayısının fazla olmasıyla açıklanmaktadır. Dramatik oyunu oynayan çocukların sayıca fazla olmaları hücreye düşen çocuk sayısını arttırmaktadır.

Tablo 3. Alana bağımlı ve alandan bağımsız çocukların oyun oynama sıklıkları açısından karşılaştırılması (Mann Whitney U -testi Sonucu)

\begin{tabular}{llllll}
\hline & & \multicolumn{5}{c}{ Sira Ort. } \\
Değişken & Grup & $\mathrm{N}$ & & $\mathrm{U}$ & $\mathrm{p}$ \\
\hline Fiziksel Oyun & Alana Bağımlı & 11 & 11,73 & 47,00 & 0,51 \\
Siklığı & Alandan Bağımsız & 10 & 10,20 & & \\
Küp Oyunu & Alana Bağımlı & 11 & 11,55 & 49,00 & 0,61 \\
Siklığ1 & Alandan Bağımsız & 10 & 10,40 & & \\
Manipülatif Oyun Sıklığı & Alana Bağımlı & 11 & 11,50 & 49,50 & 0,66 \\
& Alandan Bağımsız & 10 & 10,45 & & \\
Dramatik Oyun & Alana Bağımlı & 11 & 9,59 & 39,50 & 0,27 \\
Siklığ1 & Alandan Bağımsız & 10 & 12,55 & & \\
\hline
\end{tabular}

Tablo 3'te görüldüğü gibi alana bağımlı ve alandan bağımsız bilişsel üsluba sahip olan çocukların fiziksel, küp, manipülatif ve dramatik oyun oynama sıklığına göre farkın olup olamadığını göstermek amacıyla, Mann Whitney U testi uygulanmış ve istatiksel olarak anlamlı fark bulunmamıştır. Ancak, ortalama ve sıra ortalama değerlerinin yüksek olması göreli olarak alana bağımlı bilişsel üsluba sahip çocukların alandan bağımsız bilişsel üsluba sahip çocuklara göre daha fazla oranda fiziksel, küp ve manipülatif oyunu seçtiklerini göstermektedir. Dramatik oyunda ise bunun aksine ortalama ve sıra ortalama değerlerine göre, göreli olarak, alandan bağımsız bilişsel üsluba sahip çocukların, alana bağımlı bilişsel üsluba sahip çocuklardan daha çok dramatik oyun oynadıkları söylenebilir. 
Okulöncesi Eğitim Kurumuna Devam Eden 5-6 Yaş Grubu Çocukların... 177

Tablo 4. Alana bağımlı ve alandan bağımsız çocukların iletişim becerisi, açısından karşılaştırılması

\begin{tabular}{llllll}
\hline & & & & \\
Değişken & Grup & $\mathrm{N}$ & Sira Ort. & $\mathrm{U}$ & $\mathrm{p}$ \\
\hline Fiziksel Oyun & Alana Bağımlı & 11 & 11,23 & 52,50 & 0,83 \\
İletişim Becerisi & Alandan Bağımsız & 10 & 10,75 & & \\
Küp Oyunu & Alana Bağımlı & 11 & 11,27 & 52,00 & 0,77 \\
İletişim Becerisi & Alandan Bağımsız & 10 & 10,70 & & \\
Manipülatif Oyun İletişımim Becerisi & Alana Bağımlı & 11 & 11,09 & 54,00 & 0,93 \\
& Alandan Bağımsız & 10 & 10,90 & & \\
Dramatik Oyun & Alana Bağımlı & 11 & 8,59 & 28,50 & $0,06^{*}$ \\
İletişim Becerisi & Alandan Bağımsız & 10 & 13,65 & & \\
\hline
\end{tabular}

$* \mathrm{p}<0,10$

Tablo 4'te görüldüğü gibi, oyunda gözlemlenen iletişim becerisi ile bilişsel üslup (alana bağımlı - alandan bağımsız) arasında 0,05 düzeyinde anlamlı fark bulunmamıştır. Çocukların oynadıkları oyunda, iletişim becerisi bakımından bilişsel üslubun bir etkisi bu düzeyde $(0,05)$ görülmezken, anlamlılık düzeyinin 0,10 olması durumunda, dramatik oyunda gösterilen iletişim becerisi puanı ile alandan bağımsız bilişsel üslup puanı arasında anlamlı fark bulunmaktadır. Bu da çocuk sayısının fazla olmamasından kaynaklanmaktadır; ancak dramatik oyun oynayan çocukların iletişim becerilerinin artması yönünde bir eğilim söz konusudur.

Tablo 5.Alana Bağımlı ya da Alandan Bağımsız Bilişsel Üsluba Sahip Çocukların Liderlik Özelliği Açısından Karşılaştırılması

\begin{tabular}{lllllll}
\hline Değişken & Grup & $\mathrm{N}$ & $\overline{\mathrm{X}}$ & & $\mathrm{U}$ & $\mathrm{p}$ \\
\hline Fiziksel Oyun & Alana Bağımlı Ort. & 11 & 2,27 & 11,27 & 52,00 & 0,80 \\
Liderlik Öz. & Alandan Bağımsız & 10 & 2,10 & 10,70 & & \\
Küp Oyunu & Alana Bağımlı & 11 & 3,27 & 11,82 & 46,00 & 0,42 \\
Liderlik Öz. & Alandan Bağımsız & 10 & 2,30 & 10,10 & & \\
Manipülatif Oyun & Alana Bağımlı & 11 & 2,45 & 11,41 & 50,50 & 0,72 \\
Liderlik Öz. & Alandan Bağımsız & 10 & 2,10 & 10,55 & & \\
Dramatik Oyun & Alana Bağımlı & 11 & 11,27 & 9,95 & 43,50 & 0,41 \\
Liderlik Öz. & Alandan Bağımsız & 10 & 14,30 & 12,15 & & \\
\hline
\end{tabular}

Tablo 5'te tüm oyun sinıflamalarında gösterilen liderlik özelliğine ilişkin puanlar ile, bilişsel üslubun alandan bağımsızlık - alana bağımlılık boyutu arasında anlamlı bir ilişkinin olup olmadığı Mann Whitney U testi ile 
sınanmıştır. Analiz sonuçlarına göre, değişkenler arasında anlamlı bir farka rastlanmamıştır. Ancak, Tablo 5'ten de anlaşıldığ gibi ortalama ve sıra ortalama değerlerine göre, alana bağımlı ve alandan bağımsızlık boyutunda dramatik oyunda ortaya çıkan liderlik özelliği puanında göreli olarak, fiziksel oyun, küp oyunu ve manipülatif oyun türlerine göre, farkl1l1k söz konusudur.

Tablo 6. Çocukların Toplumsal oyun türleri ve oyun oynama puanları ile bilişsel üslup türüne göre karşılaştırılması

\begin{tabular}{|c|c|c|c|c|c|c|}
\hline Değişken & Toplumsal Oyun Türü & $\mathrm{N}$ & $\bar{X}$ & Sira Ort. & $\chi^{2}$ & $\mathrm{p}$ \\
\hline \multirow[t]{3}{*}{ Bilişsel Üslup } & 3. Paralel & 6 & 3.50 & 8.75 & \multirow[t]{3}{*}{5.23} & \multirow[t]{3}{*}{.073} \\
\hline & 4. Birlikte & 5 & 5.00 & 14.20 & & \\
\hline & 5. İşbirlikçi & 19 & 6.73 & 17.97 & & \\
\hline \multirow[t]{3}{*}{ Fiziksel Oyun } & 3. Paralel & 6 & 4.00 & 17.08 & \multirow[t]{3}{*}{0.37} & \multirow[t]{3}{*}{.829} \\
\hline & 4. Birlikte & 5 & 2.20 & 14.00 & & \\
\hline & 5. İşbirlikçi & 19 & 4.31 & 15.39 & & \\
\hline \multirow[t]{3}{*}{ Küp Oyun } & 3. Paralel & 6 & 3,66 & 17.83 & \multirow[t]{3}{*}{2.38} & \multirow[t]{3}{*}{.304} \\
\hline & 4. Birlikte & 5 & 1.00 & 11.00 & & \\
\hline & 5. İşbirlikçi & 19 & 3.47 & 15.95 & & \\
\hline
\end{tabular}

Tablo 6'da görüldüğü gibi, toplumsal oyun kategorilerinin, formda yer alan bilişsel oyun kategorisiyle, bilişsel üslup puanları arasındaki ilişki $\alpha=$ .05 düzeyinde anlamlı bulunmamıştır. Bilişsel üslup ile toplumsal oyun kategorileri arasında istatiksel açıdan anlamlı bir fark çıkmamasına rağmen, işbirlikçi oyun oynayan çocukların bilişsel üslup puanları arasında bir ilişkinin olduğu Tablo 6'da görülmektedir. Ancak bu ilişkinin istatiksel anlamda bir geçerliliği yoktur. Bilişsel üslup sınıflamalarına göre ele alındığında, literatürde alana bağımlı bireyler, alandan bağımsız bireylere göre, dış algı dayanaklarından ve diğer bireylerden gelen ipuçlarından daha fazla etkilendikleri ve bunun sonucu olarak da daha çok toplumsal olma eğiliminde oldukları Witkin ve Goodenough (1981) tarafindan ortaya konulmuştur.

Ele alınan oyun sinıflamaları ( fiziksel, küp oyunu, manipülatif ve dramatik oyun) ile toplumsal oyun kategorileri arasında da anlamlı bir ilişki bulunmamasına karşın, ortalama puanlara bakıldığında dramatik oyunun ortalamasının özellikle işbirlikçi oyunda diğer oyun türlerine göre daha yüksek bir değerde olması, göreli olarak, dramatik oyun oynayan çocukların işbirlikçi oyun oynama eğiliminde de olduklarını göstermektedir. 


\section{SONUÇ VE TARTISSMA}

Çalışmada, 5- 6 yaş grubundaki çocukların bilişsel üslupları ile oyun ve oyun davranışları arasındaki ilişki incelenmiştir. Çocuklar oyun ortamında, oyun gözlem formuna göre, zaman örnekleme tekniği kullanılarak gözlenmiştir. Çalışmanın diğer değişkeni olan bilişsel üslup puanları ise, Çocuklar için Gizlenmiş Şekiller Testi kullanılarak belirlenmiştir. Elde edilen bulgular üç farklı istatiksel yöntem (Pearson korelasyonel katsayısı (r), Mann Whitney U testi, Kruskal Wallis) kullanılarak, SPSS 10,0 paket programı ile 0.05 düzeyinde analiz edilmiştir. Genel olarak sonuçlara bakıldığında, çocukların bilişsel üslupları ile oyun ve oyun davranışları arasında bir ilişkinin olmadığ 1 görülmektedir. Bu açıdan araştırmada, çocukların bilişsel üslup puanları ve bilişsel oyun kategorileri (fiziksel oyun, inşa oyun, küp oyunu ve dramatik oyun) ve oyun davranışları (iletişim becerisi, liderlik) arasındaki ilişki, bilişsel üslup (alana bağımlı/ bağımsız) ile her bir oyun sıklı̆̆ 1 ve oyun sınıflamasındaki oyun davranışları arasındaki ilişski ve son olarak da bilişsel üslup (alana bağımlı/ alandan bağımsız) ile toplumsal oyun sınıflaması (tek başına, izleyici davranış, paralel ve işbirlikçi oyun) arasındaki ilişki ele alınmıştır. Ele alınan üç hipotez istatistiksel açıdan anlamlı bir sonuç vermemiştir.

Alana bağımlı ve alandan bağımsız olarak iki gruba ayrılan çocukların bilişsel üslupları ile oyun oynama sıklıkları ve oyun davranışları arasındaki ilişki incelenmiştir. Araştırmanın sonunda, değişkenler arasında anlamlı fark bulunmamıştır. Ancak, alandan bağımsız çocukların, göreli olarak, diğer oyun gruplarına göre daha çok dramatik oyun oynama eğiliminde oldukları saptanmıştır. Ayrıca çalışmanın amacıyla ilgisi olmayan ama belirtilmesi gereken önemli bir nokta ise Kogan'1n (1987) da belirttiği gibi, 5 ve 6 yaşlarındaki çocukların bilişsel üslup puanları alandan bağımsızlık yönünde bir değişim gösterme eğiliminde olmasıdır. Örneklem grubunun yaş özellikleri dikkate alınarak, hem bilişsel üslup puanları hem de oyun oynama eğilimleri bakımından çocukların büyük bir kısmının belli bir noktada toplandığı görülmektedir: Dramatik oyun oynayan çocuklar daha fazla alandan bağımsızlardır.

Çalışmanın son aşaması olarak, alana bağımlı/ bağımsız bilişsel üsluba sahip çocukların oynadıkları toplumsal oyunlarda farklılık ele alındı̆̆ında, böyle bir farklı1ığın olmadığı saptanmıştır. Ancak alandan bağımsız çocukların diğer toplumsal oyunlara göre, göreli olarak, daha çok işbirlikçi oyun oynadıkları bulunmuştur. 
Çalışmada bir başka bulgu ise Parten'ın (1932) toplumsal oyun sınıflamasıyla aynı sonuçları göstermektedir: toplumsal oyun sınıflaması yaşa göre değişim göstermektedir, bu değişime bağlı olarak, 4 yaştan itibaren, tercih edilen oyun türleri; paralel, birlikte ve işbirlikçi oyundur. Çalışmanın örneklemini 5-6 yaş çocukların oluşturması ile bu oyun türlerinin seçilmesinde etkili olmaktadır.

Çalışmada elde edilen veriler topluca değerlendirildiğinde, ilk olarak, bilişsel üslubun zaman içinde değişime uğraması olasıllğg üzerinde durmakta yarar vardır. Bu konuda ilk yapılan çalışmalara baktığımızda, çocukların bilişsel üslubunu değerlendiren testlerin günümüzdeki değişimin gerisinde kaldığ 1 , daha çok görsel özelliklere göre değerlendirme yapan testler olduğu saptanmıştır. Buna örnek olarak; Eşleştirilmiş Benzer Şekiller Testi, Gizlenmiş Şekiller Testi gibi testler gösterilebilir. 21. Yüzyılın başlangıcında olduğumuz bir dönemde, özellikle modernleşme ile ortaya çıkan, çocuklara yönelik okul programları, faaliyetler, oyun etkinlikleri daha yapılandırılmış ve bireyselliği ön plana çıkaran bir sistem oluşturmaya başlamıştır. Çocuklar artık kitle iletişim araçlarını daha etkili kullanmaktadırlar. Dolayısıyla bilişsel üslubun ölçülmesinde günümüz şartlarına göre "normal" olarak değerlendirilen çocuklar, önceki dönemlerde çocukların bilişini doğrudan etkileyen bu testlerden daha yüksek puanlar almakta ve bu etki çalışmayı yanlış yönlendirilecek sonuçlar çıkarılmasına neden olmaktadır. Bunu en iyi açıklayan ve yeni bir bilişsel üslup tanımı yapan, Stenberg ve Griengko (1997) zihinsel kendini yönetme kuramiyla (theory of mental-self government) kişiye ve onun bulunduğu çevreye dikkat çekmiştir. Sonuç olarak şunu söylemek mümkün; "bilişsel üslubu kullanırken, toplumda oluşan değişimi de gözardı etmeden bir değerlendirme yapmak" yerinde ve doğru bir davranış olmaz. Bireyi içinde bulunduğu toplumun ve zamanın özelliklerine göre değerlendirmek gerekliliği ortaya çıkmaktadır.

İkinci önemli değerlendirme çocukların oynadıkları oyunların gözlenmesine ilişkindir. Bilindiği üzere gözlem yöntemini kullanmak hem zahmetli hem de öznelliği olan, hata olasılığı oldukça yüksek bir yöntemdir. $\mathrm{Bu}$ konuda oyun ortamında gözlemlenen çocukların oynadığı oyunlara ilişkin bir değerlendirme yapıldığında, bu değerlendirmenin geçerli bir şekilde yapılmaması söz konusu olabilir. Çünkü hem oyunun tanımlanmasına ilişkin birtakım sorunlar olması hem de gözlem yaparken kullanılan zaman örnekleme yönteminin kısıtlı bir gözlem olanağı vermesi geçerli sonuçlara ulaşmayı zorlaştırmış olabilir. Örneğin, bizim oyun diye tanımladığımız nedir? Neye göre çocuk bu oyun sınıflamasına dahil olmaktadır? gibi sorunlar oyun konusunda yapılan çalışmaların en temel sorunlarının başında gelmektedirler. 


\section{KAYNAKLAR}

Coates, S., Lord, M. ve Jocabivics. (1975). Field dependent- independent social - nonsocial play and sex difference, Perceptual and Motor Skills, 40,195-202.

Coates, S.(1972). Preschool Embeded Figures Test, Palo Alto, CA: Consulting Psychologist Press.

Dansky, J.L.(1980). Make-believe; A mediator of the relationship between play and associative fluency, Child Development, 51,560-579.

Eckler, J.A. ve Weininger, O.(1988). Play and cognitive development in preschoolers: A critical review, The Albert Journal of Educational Research, 34(2),179-193.

Gruenfeld,L.W., Linn,T.R.(1984). Social behavior of field indepents and depents in an organic group, Human Relation, 37(9), 721-741.

Kagan, J. ve Kogan, N.(1970). Individual in cognitive processes, Carmichael's Manual of Child Psychology, 1, New York: Wiley.

Kagan, J. ve Messick, F.(1976). Group Embedded Figures Test: Normative data for male automotive mechanical apprentice tradesman. Perceptual and Motor Skills, 60, 803-806.

Karp, S.A. ve Konstandt, N. (1971). The Children's Embeded Figures Test (CEFT). H.A.Witkin, P.K. Oltman, E. Raskin ve S.A.Karp (Eds.), Manual for the Embeded Figures Tests (sf:21-26), Palo Alto, CA: Consulting Psychologists Press.

Kogan, N.(1971). Educational implications of cognitive styles, Psychology and Educational Practice, Glenview: Scott- Foresman.

Kogan, N.(1987). Some behavioral implications of cognitive styles in childhood, Early Child Development and Care, 29, 95-117.

Kogan, N.(1989). Cognitive style in children: Some evolving trends, Early Child Development and Care, 43, 101-128.

Kogan, N. ve Block, J.(1991). Field depence- indepence from early childhood thorough adolescence: Personality and socialization aspects, S. Wapner ve J. Demick (Eds), Field Depence-Indepence Cognitive Style Across The Life Span (içinde) 177-207.

Mellon, E.(1994). Play theories: A contemporary view. Early Child Development and Care,102, 91-100.

Piaget, J.(1962). Play, dreams and imitation in children, New York: Norton.

Piaget, J.(2002). The Psychology of Intelligence, (Çev: Malcom Piercy, D.E. Berlyne), London: Routlegde.

Rubin, K. ve Coplan, J.R.(1998). Social and nonsocial play in childhood: An individual differences perspective, Canada: University Waterloo Press.

Rubin, K.H., Fein, G., Vanderberg, B.(1983). Play, H.Musson (Eds), Handbook of Child Psychology (İçinde), 4, New York: Wiley.

Saracho, O. (1984). Construction and validation of the play rating scale. Early Child Care and Education, 17,199-230. 
Saracho, O (1985). The Relationship between the cognitive styşes and play behaviours of pre-school children, Educational Psychology, 4(15), 405416.

Saracho, O.(1986). Play and Young children's learning, B. Spodek (Eds), Today's Kindergarden: exploring the knowledge base, expanding the curriculum (içinde), The New York Teachers College Press, 91-109.

Saracho, O.(1987). Cognitive style in the play of young children, Early Child Development and Care, 51, 65- 72.

Saracho, O.(1995).The relationship between the cognitive styles and play behaviours of pre-school children, Educational Psychology, 4(15), 405428.

Saracho, O.(1996). Preschool children's cognitive styles and play behaviors, Child Study Journal, 26, 125-148.

Saracho, O. (1999). A factor analysis of pre-school children's play strategies and cognitive style, Educational Psychology, 19(2), 165-181.

Saracho, O. ve Spodek, B.(1981). The teachers' cognitive styles and their educational implications. Educational Forum, 45(2), 153-159.

Saracho, O. ve Spodek, B.(1998). Multiple Perspectives on play in early childhood education, Albany: New York: State University of New York Press.

Smalucha, L. ve Smalucha, F.(1998). The social origins of mind: postpiagetian perspectives on pretend play, O.Saracho ve B.Spodek (Eds), Multiple Perspectives on play in early childhood education (içinde), State University of New York Press, Albany: New York.

Smith, K.P. ve Simon, T.(1985). Object play, problem solving, creativity, Social Science Research Council, 199-216.

Steele, C. (1981). Play variables as related to cognitive in three- to six yearold, Journal of Research and Development in Education, 14, 58-72.

Stenberg, R.ve Grigorenko, E. (1997). Are cognitive styles stil in style? American Psychologist, 52(7), 700-712.

Vygotsky, L. (1967). Play and its role in the mental development of the child, Soviet Psychology, 5, 6-18.

Witkin, H.A. ve Goodenough, D.R.(1981). Cognitive style: Essence and Origins, Westport, CT: Greenwood Press.

Witkin, H.A., Dyk., R.B., Faterson, H.F., Goodenough, A.R. ve Karp, S.A.(1962). Psychological Differentation, Potomac, MD: Erlbaum Associates.

Witkin,H.A., Lewis, H.B., Hertzman, M., Machover, K., Meissner, P.B. ve Wapner, S.

(1972). Personaly through perception: An experimental and clinical study, Westport, CT: Greenwood Press.

Witkin, H.A., Oltman P.K., Raskin E., ve Karp, S.A.(1971). Manual for embededed figures test, children's embeded figures test, and group emebeded figures test. Palo Alto, CA: Consulting Psychologists Press, Inc. 